(C) 1992 ISIJ

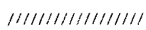

論 文

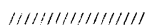

\title{
鉄鉱石粉の熱分解反応速度
}

\author{
肖 興国 ${ }^{*} \cdot$ 清水 正賢 $* 2 \cdot$ 稲葉 晉一 $* 2$
}

\section{Thermal Decomposition Rate of Fine Iron Ore}

Xing-guo XIAo, Masakata SHIMIZU and Shin-ichi INABA

Synopsis :

In order to clarify the thermal decomposition behavior of fine iron ore which is injected into the raceway of a blast furnace, thermal analyses of fine iron ore have been made under various atmospheric conditions $\left(\mathrm{N}_{2}, \mathrm{CO}_{2}\right.$, air, $\mathrm{O}_{2}$ and $\mathrm{N}_{2}+\mathrm{O}_{2}$ with different oxygen concentrations from $1 \%$ to $25 \%$ ), particle size (average dia. : 55, 155 and $325 \mu \mathrm{m})$ and heating rate $(0.033,0.167$ and $0.33 \mathrm{~K} / \mathrm{s}$ ). A kinetic analysis of the reaction $\left(3 \mathrm{Fe}_{2} \mathrm{O}_{3}=2 \mathrm{Fe}_{3} \mathrm{O}_{4}+1 / 2 \mathrm{O}_{2}\right)$ has been made based on measured thermalgravimetric curves by the Coats' method. Its results show that the reaction rate could be described by a second order reaction rate equation with relation to unreacted degree.

$$
\begin{aligned}
& d \alpha / d \mathrm{t}=k(1-\alpha)^{2} \\
& k=\exp (A-E / R T)
\end{aligned}
$$

Furthermore it was found that the starting temperature $\left(T_{D 1}\right)$ and the kinetic behavior of the reaction were independent of the particle size in the range from 55 to $325 \mu \mathrm{m}$. However, they were strongly affected by the oxygen potential of the gas atmosphere. Empirical equations to estimate $T_{D 1}, E$ and $A$ were obtained as a function of $P_{\mathrm{O}_{2}}$ in the gas atmosphere as follows:

$$
\begin{aligned}
& T_{D 1}=75560 /\left\{44.56-\ln \left[P_{\mathrm{O}_{2}} /\left(1.013 * 10^{5}\right)\right]\right\} \\
& E=20730 /\left\{6.543-\ln \left[P_{\mathrm{O}_{2}} /\left(1.013 * 10^{5}\right)\right]\right\} \\
& A=\left\{14.43+\ln \left[P_{\mathrm{O}_{2}} /\left(1.013 * 10^{5}\right)\right]\right\} * 10^{2} / 6.9306
\end{aligned}
$$

Using these equations, the thermal decomposition processes of iron ore were analyzed under various conditions and the results coincided well with our experimental results. Under heating conditions simulating raceway in a blast furnace, it was predicted that the injected fine iron ore could be almost decomposed from $\mathrm{Fe}_{2} \mathrm{O}_{3}$ to $\mathrm{Fe}_{3} \mathrm{O}_{4}$ in the raceway.

Key words : thermal decompositions; iron ore; thermal analysis; kinetic analysis; injection of fine ore; raceway; blast furnace.

\section{1. 緒}

\section{言}

高炉の羽口から粉鉱石あるいは粉鉙石と微粉炭を同時 に吹き込む新しい高炉操業技術の開発が各社で注目され ている ${ }^{1)-8)}$. 羽口からの微粉炭吹迟みに関しては, レー スウェイ域での微粉炭の高速燃焼反忍に関する数学モデ ルや燃焼実験結果がいくつか発表され，燃焼挙動がかな

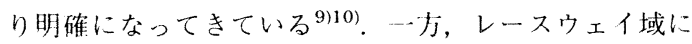
吹き迟まれた粉鉱石の挙動については，Si 低減のため の脱珪友応についての考察，あるいは小型実験炉および 数式モデルによる粉鉱石吹计み限界量の推定が行われて いるのみで11)12), レースウェイ内での反心举動につい ての速度論的検討は十分ではない. 高炉レースウェイ内 のガスサンプリング結果 ${ }^{9113)}$ によれば, 羽口から流入し
た熱風はコー・クスな゙の燃焼により，酸素分压が下が り、温度が急速に上舁し, 最高温度に達したのち, 徐々 に温度が下がり，その組成が還元性に变化していくここ のようなレースウェイ内に粉鉱不を吹き込んだ場合，粉 鉱石の父応挙動を熱力学的に考察すると, 急速な昇温 とともに鉣石中の $\mathrm{Fe}_{2} \mathrm{O}_{3}$ はまず熱分解文応によって， $\mathrm{Fe}_{3} \mathrm{O}_{4}$ に変化し，その後，還元が進行するものと予想 己れる， $\mathrm{Fe}_{2} \mathrm{O}_{3}$ の熱分解に関す万従来の研究 ${ }^{14)-18)}$ はそ の多くが熱力学的検討に留まっており，速度論的な研究 は見られない。レースウェイ内での羽口から吹き迟まれ た粉鉣不の反忍挙動を解明し，適正な吹认み条件を検討 していくためには，還元に先立って進行すると尒想され る粉鉱不の熱分解挙動を速度論的に解明することが重要 と考えられる。

平成 3 年 4 月本会講演大会にて発表 平成 3 年 4 月 26 日受付 (Received Apr. 26, 1991)

* (株) 神下製鋼所鉄鋼技術研究所 (Iron \& Steel Research Laboratories, Kobe Steel, Ltd., 1-3-18 Wakinohama-cho Chuo-ku Kobe 651)

*2. (株)神厂製鋼所鉄鋼技術研究所 J博（Iron \& Steel Research I.aboratories, Kobe Steel. Ltd.) 
Table 1. Chemical composition of iron ore $(\operatorname{mass} \%)$.

\begin{tabular}{ccccc}
\hline $\mathrm{Fe}_{2} \mathrm{O}_{3}$ & Combined water & $\mathrm{FeO}$ & $\mathrm{SiO}_{2}$ & $\mathrm{Al}_{2} \mathrm{O}_{3}$ \\
\hline 89.66 & 2.80 & 0.41 & 3.80 & 2.39 \\
\hline
\end{tabular}

そこで，示堼熱天种を朋いて，ガス種，酸素分压，粉 鉱不粒度および界温速度などが䀧なる条件下で粉鉱石の 熱分析を行い，粉鉣不の熱分解又忘について速度䛺的に 検討した。

\section{2. 実験}

\section{$2 \cdot 1$ 試料}

実験にはオーストラリア産のハマスレ一鉄鉱石を用い た. Table 1 にその化学分析值を亦す。鉱石は粉砕後,

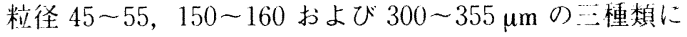
分級して実験に供した。また、雲网気調整用ガスとして， 酸素、等素, 空気, $\mathrm{CO}_{2}$ および酸素濃度の異なる $\mathrm{N}_{2}$ と $\mathrm{O}_{2}$ の混令ガス $\left(\mathrm{N}_{2} / \mathrm{O}_{2}=99 / 1,95 / 5,90 / 10,85 / 15\right.$, 75/25）を用いた。

\section{$2 \cdot 2$ 実験方法}

理学電機(株)製熱分析装㯰 (高温型 TG-DTA 8078G2) を用い，所定のガス雲用気下で定速昇温時の熱分析を 行った。測走に際しては，一槽からなるアルミナ製ホル ダー (内径 $0.0037 \mathrm{~m}$ ) の片方に約 $0.03 \mathrm{~g}$ の)粉鉣石を, また，もう一开には標準物質( $\alpha$-アルミナ)を層高約 $0.002 \mathrm{~m}$ に充填した。 ホルダー下部から雲囲気調整用ガ スを䄪 $2.5 * 10^{-6} \mathrm{Nm}^{3} / \mathrm{s}$ (ホルダー位㯰でのガスの空塔 流速は標準状態で約 $\left.7.2 * 10^{-3} \mathrm{~m} / \mathrm{s}\right)$ 流しつつ, 所走の 昇温速度 (常温から $1773 \mathrm{~K}$ まで約 $0.033,0.167$ と $0.33 \mathrm{~K} / \mathrm{s}$ の三水準)で加熱した。試料側の温度 ( $\mathrm{T}$ 曲 線) および試料側と標準物質側との起電力差（DTA 曲 線)を Pt $87 \mathrm{Rh}$ 13-Pt 熱電対を用いて測定した。これ ら実験条件のうち, 特に試料の充填量については, 熱分 解文応が㕬散および伝熟に律速されず，しかも測走精度 上問題のないことを考慮して設走した。

\section{3. 実 験 結 果}

Fig. 1 に粉鉣石の熱分析によって得られた TG（熱重 量変化) と DTA (示差熱分析) 曲線の一例を示す。汹 中の昇温曲線（ $T$ ) は試料ホルダー側の温度変化であ る. TG曲線には三つの重量変化部が現れる. $773 \mathrm{~K}$ 以 下の領域に現れる“つの重量変化部は脱結晶水, 1573 $\mathrm{K}$ 以上の領域に現れる重量变化部は $\mathrm{Fe}_{2} \mathrm{O}_{3}$ の熱分解反 㐫に相当すると考えられる，また，熱分解反忘が開始す ると DTA 曲線が急激に変化し，この変化幅から反応の

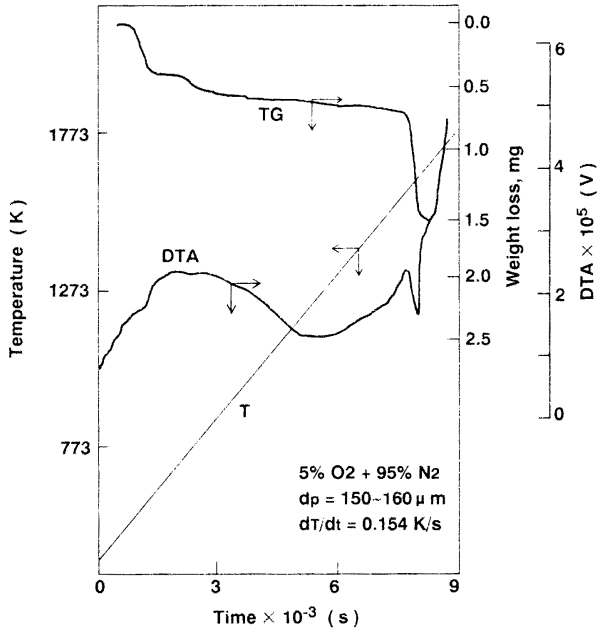

Fig. 1. An example of recorded TG and DTA curves.

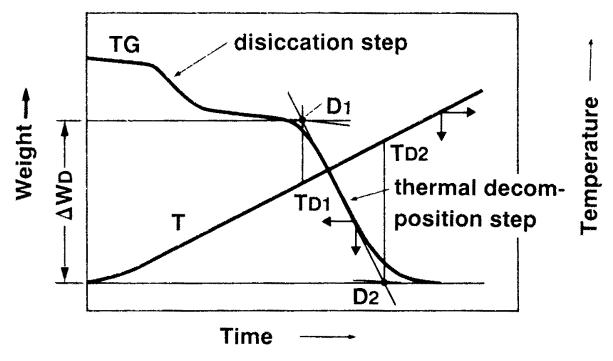

1: Strat moment $2:$ End moment

Fig. 2. The determination method of start and end moments for reactions from a TG curve.

律速因子を推定することができる．Fig. 1 および他の実 験条作下での DTA 曲線の変化幅を温度差に換算すると 0.2 1.2 K 程度であった。 したがって，本実験条件で は熱分解反応に及ぼす伝熱の影響は小さく，見掛け上， 反応律速であると判断される. Fig. 2 に示した方法で, TG 曲線から熱分解反忍の開始温度 $\left(T_{D 1}\right)$ と終了温度 $\left(T_{D 2}\right)$ 抢よび重量減少量 $\left(\Delta W_{D}\right)$ が求められる. 15 種 類の実験条件から得られた TG 曲線の解析結果を実験 条件とともにまとめて, Table 2 に示した.

鉄鈗石中 $\mathrm{Fe}_{2} \mathrm{O}_{3}$ の熱分解反忘については次の反応式 が考えられる。

$$
\begin{aligned}
& 3<\mathrm{Fe}_{2} \mathrm{O}_{3}>=2<\mathrm{Fe}_{3} \mathrm{O}_{4}>+1 / 2\left(\mathrm{O}_{2}\right) \cdots \cdots \cdots \cdot(1) \\
& \text { ここで, 鉄鉱石の熱分解率を次式で定義する. } \\
& \alpha=\left(N_{\mathrm{Fe}_{2} \mathrm{O}_{3}}^{0}-N_{\mathrm{Fe}_{2} \mathrm{O}_{3}}^{t}\right) / N_{\mathrm{Fe}_{2} \mathrm{O}_{3}} \cdots \cdots \cdots \cdots \cdots \cdots \cdots(2)
\end{aligned}
$$

分解前の鉱石中 $\mathrm{Fe}_{2} \mathrm{O}_{3}$ の重量を $W_{0}$ とし, 熱分解に 伴う重量变化を $\Delta W_{t}$ とすると, 反応に関する物質の分 


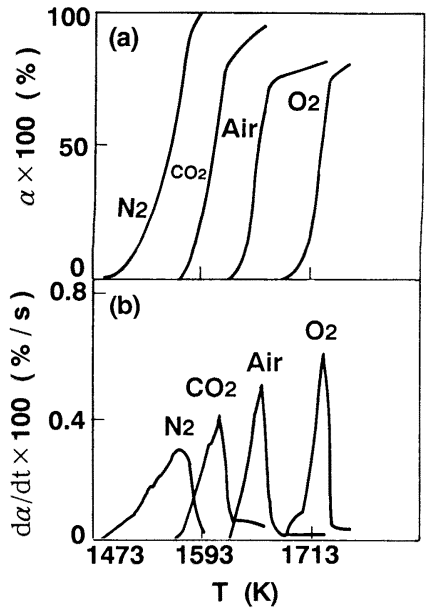

(i) Effect of gases.

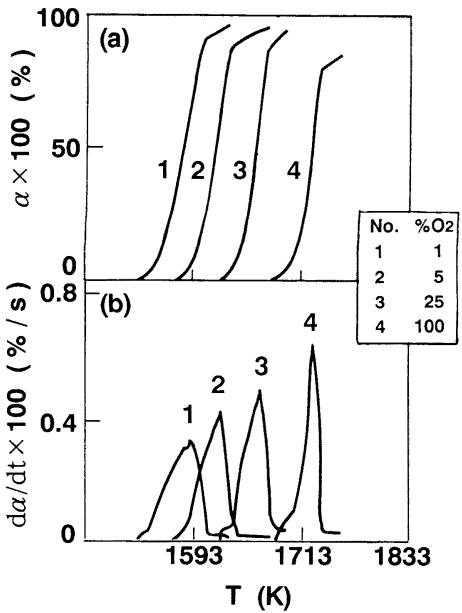

(ii) Effect of oxygen partial pressure.

(a) $\alpha$ vs. $T$ (b) $d \alpha / d t$ vs. $T(d p=150 \sim 160 \mu \mathrm{m}, d T / d t=0.167 \mathrm{~K} / \mathrm{s})$

Fig. 3 Kinetic characteristics of the thermal decomposition reaction of iron ore at gases flow or oxygen partial pressures.

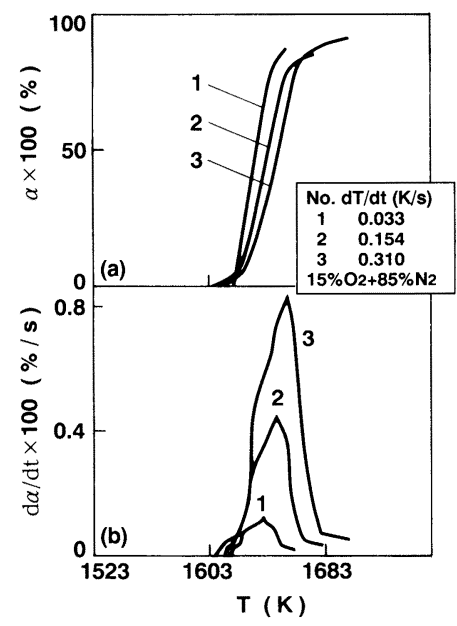

(i) Effect of $\mathrm{dT} / \mathrm{dt}$

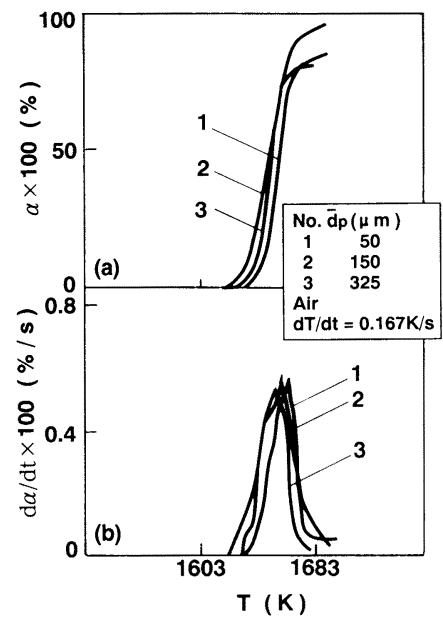

(ii) Effect of $\overline{d p}$ (a) a vs. $T$ (b) $d \alpha / d t$ vs. $T$

Fig. 4. Kinetic characteristics of the thermal decomposition reaction of iron ore at different $d T / d t$ and $d p$.
子量を考慮して次式が得られる.

$$
\alpha=29.95 \Delta W_{t} / W_{0}
$$

( 3 )式を適用することによって各 TG 曲線に対する $\alpha$ と $T($ あるいは $t)$ の関係が計算できる. Fig. 3, Fig. 4 には異なるガス種 $\left(\mathrm{N}_{2}, \mathrm{CO}_{2}\right.$, 空気および $\left.\mathrm{O}_{2}\right)$ と酸素 濃度 ( $1 \%$ から $100 \%$ まで) 雲囲気, および異なる昇温 速度と粒度に対して得られた $\alpha$ および $d \alpha / d t$ と温度 $T$ との関係を示した。また，Fig. 5 には異なる昇温速度の 条件下で得られた $\alpha$ および $d \alpha / d t$ と時間 $t$ との関係を 示した。
Table 2 および Fig. 3〜Fig. 5 の結果から, 鉄鉱石の 熱分解挙動として以下の特性が見いだされた.

1 )熱分解反応に及ぼす粒径の影響は小さい。

2 ) 分解温度, 分解速度および最終分解率は雲囲気の ガス種類と酸素ポテンシャル $\left(P_{\mathrm{O}_{2}}\right)$ によって変化する.

3 ) 熱分解温度および反心速度は雲囲気が $\mathrm{N}_{2}, \mathrm{CO}_{2}$, 空気, $\mathrm{O}_{2}$ の順に,また,酸素分圧が高くなるにしたがっ て上昇し, 最終分解率は逆に低下傾向を示す.

4 ) 昇温速度は分解開始温度にはほとんど影響しな い.しかし, 分解終了温度は昇温速度の増大とともに高 


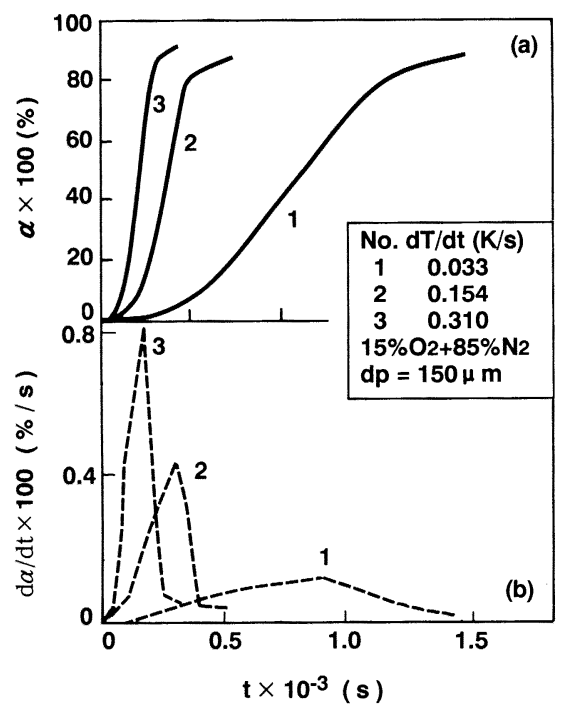

$\begin{array}{lll}\text { (a) } a v s . t & \text { (b) } d a / d t \text { vs. } t\end{array}$

Fig. 5. Decomposition curve at different rising rate of temperature.

温側に移行し，分解速度も著しく大きくなる．また，熱 分解の起こる時間範囲から見ると, 昇温速度が増大する ほど, 熱分解の開始と終了が早くなる. さらに, 分解速 度曲線が狭くなり，そのピークが高くなる。

\section{4. 考察}

\section{$4 \cdot 1$ 鉄鉱石の熱分解温度}

$\mathrm{Fe}_{2} \mathrm{O}_{3}$ の熱分解温度に及ぼす酸素分圧の影響は熱力 学的に予測可能である. 反応式（1)の標準 Gibbs エネ ルギー変化と平衡定数は次式で与えられる.
Table 2. Experimental conditions and results.

\begin{tabular}{|c|c|c|c|c|c|c|}
\hline \multirow{2}{*}{$\begin{array}{l}\text { Run } \\
\text { No. }\end{array}$} & \multicolumn{3}{|c|}{ Conditions } & \multicolumn{3}{|c|}{ Results } \\
\hline & $\begin{array}{l}d T / d t \\
(\mathrm{~K} / \mathrm{s})\end{array}$ & Gas & $\begin{array}{l}d p \\
\mu \mathrm{m})\end{array}$ & $\begin{array}{l}T_{D 1} \\
(\mathrm{~K})\end{array}$ & $\begin{array}{l}T_{D 2} \\
(\mathrm{~K})\end{array}$ & $\begin{array}{l}\Delta W_{D} \\
(\mathrm{mg})\end{array}$ \\
\hline $\begin{array}{l}1 \\
2 \\
3 \\
4\end{array}$ & $\begin{array}{l}0.151 \\
0.156 \\
0.153 \\
0.149\end{array}$ & $\begin{array}{l}\mathrm{N}_{2} \\
\mathrm{~N}_{2} \\
\mathrm{~N}_{2} \\
\mathrm{CO}_{2}\end{array}$ & $\begin{array}{r}45 \sim 55 \\
150 \sim 160 \\
300 \sim 355 \\
150 \sim 160\end{array}$ & $\begin{array}{l}1526 \\
1518 \\
1515 \\
1576\end{array}$ & $\begin{array}{l}1588 \\
1582 \\
1575 \\
1619\end{array}$ & $\begin{array}{l}0.95 \\
0.91 \\
0.93 \\
0.86\end{array}$ \\
\hline $\begin{array}{l}5 \\
6 \\
7\end{array}$ & $\begin{array}{l}0.151 \\
0.156 \\
0.156\end{array}$ & $\begin{array}{l}\mathrm{Ai} \\
\mathrm{Ai} \\
\mathrm{Ai}\end{array}$ & $\begin{array}{r}45 \sim 55 \\
150 \sim 160 \\
300 \sim 355\end{array}$ & $\begin{array}{l}1641 \\
1633 \\
1640\end{array}$ & & $\begin{array}{l}0.75 \\
0.74 \\
0.78\end{array}$ \\
\hline $\begin{array}{r}8 \\
9 \\
10 \\
11 \\
12 \\
13 \\
14\end{array}$ & $\begin{array}{l}0.153 \\
0.151 \\
0.154 \\
0.033 \\
0.154 \\
0.310 \\
0.153\end{array}$ & $\begin{array}{r}1 \% \mathrm{O}_{2}+99 \% \\
5 \% \mathrm{O}_{2}+95 \% \\
10 \% \mathrm{O}_{2}+90 \% \\
15 \% \mathrm{O}_{2}+85 \% \\
15 \% \mathrm{O}_{2}+85 \% \\
15 \% \mathrm{O}_{2}+85 \% \\
25 \% \mathrm{O}_{2}+75 \%\end{array}$ & $\begin{array}{l}150 \sim 160 \\
150 \sim 160 \\
150 \sim 160 \\
150 \sim 160 \\
150 \sim 160 \\
150 \sim 160 \\
150 \sim 160\end{array}$ & $\begin{array}{l}1546 \\
1588 \\
1605 \\
1620 \\
1621 \\
1624 \\
1638\end{array}$ & & $\begin{array}{l}0.77 \\
0.78 \\
0.78 \\
0.80\end{array}$ \\
\hline 15 & 0.163 & $\mathrm{O}_{2}$ & $150 \sim 160$ & 1705 & 1730 & 0.75 \\
\hline
\end{tabular}

$$
\begin{aligned}
& \Delta G^{\circ}=a+b T \cdot \ldots \ldots \ldots \ldots \ldots \ldots \ldots \ldots \\
& K=\exp \left(-\Delta G^{\circ} / R T\right)=\left(P_{\mathrm{O}_{2}}, e\right)^{1 / 2}
\end{aligned}
$$

$P_{\mathrm{O}_{2}}, e$ は酸素の平衡分圧, $a$ と $b$ は常数である. (4)，（5)式から求めた $\mathrm{Fe}_{2} \mathrm{O}_{3}$ の熱分解温度 $\left(T_{D}\right)$ の 曲線 ${ }^{14) ~ 18)}$ と実験で得られた $T_{D 1}$ および $T_{D 2}$ を酸素分 圧の関数として Fig. 6 (a) に示す. 研究者により, 熱 力学的な $a$ と $b$ の值が異なるため, 曲線は大きくばら ついている.また， $T_{D 1}$ については各曲線とも実測值と 比較して約 $20 \mathrm{~K}$ 以上のずれを有している。 そこで，実 験結果を用いて，鉄鉱石の熱分解開始温度と酸素分圧の 関係について解析した。

(4)式と(5)式から次式が導かれる.

$\ln \left(P_{\mathrm{O}_{2}}, e\right)=a^{\prime}+b^{\prime} / T$

(6)式において, $\ln \left(P_{\mathrm{O}_{2}}, e\right)$ と $1 / T$ は直線関係にあ るので, 空気, 酸素および異なる濃度の $\mathrm{N}_{2}$ と $\mathrm{O}_{2}$ の混
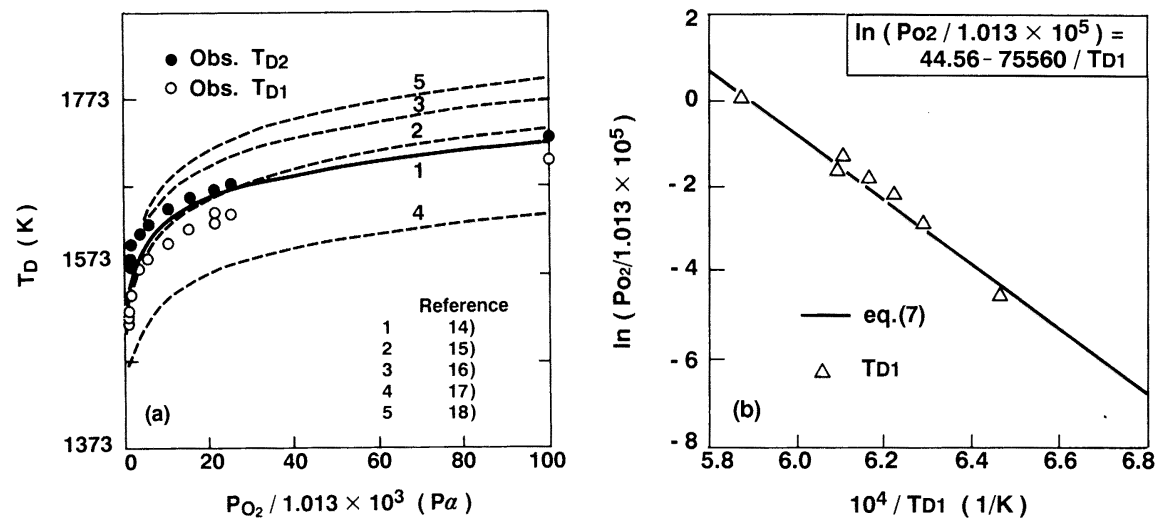

(a) Composition between observed $T_{D 1}, T_{D 2}$ and thermodynamic calculating curves

(b) The linear correlation between $\ln \left(P_{\mathrm{O}_{2}}\right)$ and $T_{D 1}$

Fig. 6. Thermal decomposition temperatures of iron ore at different oxygen partial pressure. 
今笛ス雲囲気で得られた $1 / T_{D 1}$ 扩よび対心する $\left(P_{\mathrm{O}_{2}}\right)$ をプロットすると Fig. 6（b）が得られた。また， 网中の值線は最小自乗法により求めた回帰線である。そ の直線は $(7)$ 式で示され，相関関数は $98.9 \%$ である.

$$
T_{D 1}=75560 /\left\{44.56-\ln \left[P_{\mathrm{O}_{2}} /\left(1.013 * 10^{5}\right)\right]\right\}
$$

\section{$4 \cdot 2$ 鉄鉱石の熱分解反応に関する速度論解析}

異なるガス雲用気および昇温速度下での熱分解反心心 ついて速度論的に解析した。解析にあたっては，固体一 気体の不均一系分解反応に対する従来の解析手法 ${ }^{19)}$ - 22

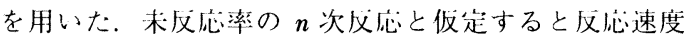
は次式で学えら机る。

$$
d \alpha / d t=k(1-\alpha)^{n}
$$

熱分解反底速度が気相中の酸素分圧に依存することは 実騃デー夕より明白であり，式中に酸素分圧の項を含め るべきではあるが，ここでは，従来使用されている簡便 な解析法を適用するため，その項を( 8 )式中には含めな かったしたがって（（）式中の $k$ は見かけの反心速 度定数であり， $k$ に酸素分圧の影響も含まれることにな る。

見かけの反忍速度定数が Arrhenius 型の式で表現で きるとすると，

$$
k=\exp (A-E / R T)
$$

(8)式と(9)式より,

$$
\begin{aligned}
& d \alpha / d t=\exp (A-E / R T)(1-\alpha)^{n} \\
& \text { 未反応率 }(1-\alpha) \text { を } X \text { と置くと, } \\
& -d X / d t=-(d X / d T)(d T / d t) \\
& \quad=\exp (A-E / R T) X^{n} \ldots \ldots \ldots \ldots \ldots \ldots . . .
\end{aligned}
$$

走速昇温であるので(11)式を書き換えれば，

$-d X / d T=(1 / B) \exp (A-E / R T) X^{n}$

ここで $B$ は昇温速度 $(d T / d t)$ である。 $\operatorname{CoATs}^{22)} に よ$ り提案された積分法を用いて，(12)式を変数分離し積分 すれば，

$-\int d X / X^{n}=(1 / B) \int \exp (A-E / R T) d T$

(13)式の右辺を級数展開し，第三項以降を無視すると 次式が得られる.

$$
\begin{aligned}
& n \neq 1 \text { の場合 } \\
& \begin{array}{l}
\ln \left[\left(1-X^{1-n}\right) / T^{2}(1-n)\right] \\
\quad=\ln \left[\left(e^{A} R / B E\right)(1+2 R T / E)\right]-E / R T
\end{array}
\end{aligned}
$$

$n=1$ の場合

$\ln \left(-\ln X / T^{2}\right)=\ln \left[\left(e^{\mathrm{A}} R / B E\right)\right.$

$\cdot(1+2 R T / E)]-E / R T$

-..般の化学反応では $2 R T / E \ll 1$ の条件を満足するの で，(14)式と(15)式の有辺第一項はほぼ走数であると見
なせる。そこで, 反応次数 $n$ を佊走して実測デー夕か ら(14)式あるいは(15)式の左辺を計算し，これを $1 / T$ に対してプロットすると，佊垐した $n$ が正しければ直 線が得られ，その幻配から $E$ の值が得られる。また， 切片からAの扩扩よその值が推定できる。

以上の方法でハマスレー鉄鉱不の TG 曲線を解析し たＦig. 7 に赤すように，実測デー夕は異なる実験条件 に执いても， $n=2$ の場命に(14)式の直線関倸をほほ満 足することか判明した。各条件に対する值線の勾配と切 片から求めた $A$ と $E$ の储を Table 3 にまとめて示す。

$E$ と $A$ の值は需同気の酸素分座が高くなるにしたがって 上昇する。純酸素雲讲気中の $E$ の值が約 $2770 \mathrm{~kJ} / \mathrm{mol}$ と非常に大きい值であり，純㮫素雲网気中のそれは前者 の約半分程度である。また， $\mathrm{O}_{2}+\mathrm{N}_{2}$ 系では，酸素濃 度が $5 \%$ 以上になると， $A, E$ 共に上昇率が小さくなっ ている。さらに， $15 \% \mathrm{O}_{2}+85 \% \mathrm{~N}_{2}$ 雲井気中での昇温

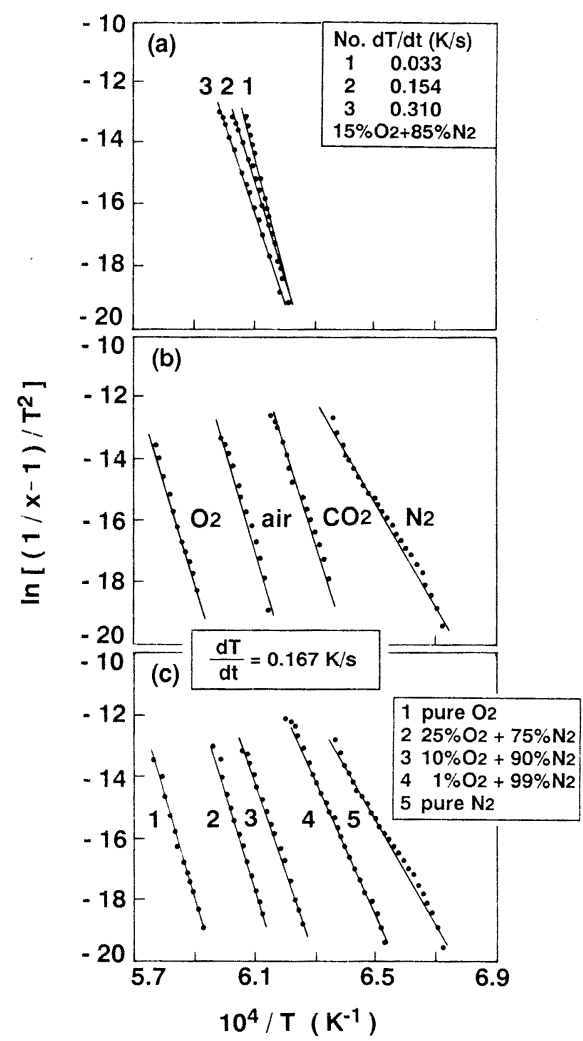
(a) Different rising rate of temperature
(b) Different gas
(c) Different oxygen partial pressure $d p=150-160 \mu \mathrm{m}$

Fig. 7. Kinetic analysis under different conditions. 
Table 3. $E$ and $A$ obtained by Eq. (14) (Coats method).

\begin{tabular}{c|c|c|c}
\hline Gas & $d T / d t(\mathrm{~K} / \mathrm{s})$ & $E(\mathrm{~kJ} / \mathrm{mol})$ & $A$ \\
\hline $\mathrm{N}_{2}$ & 0.156 & 1390 & 105 \\
$\mathrm{CO}_{2}$ & 0.149 & 2620 & 192 \\
$\mathrm{Air}$ & 0.156 & 2750 & 196 \\
$\mathrm{O}_{2}$ & 0.163 & 2770 & 189 \\
\hline $1 \% \mathrm{O}_{2}+99 \% \mathrm{~N}_{2}$ & 0.153 & 1800 & 132 \\
$5 \% \mathrm{O}_{2}+95 \% \mathrm{~N}_{2}$ & 0.151 & 2330 & 169 \\
$10 \% \mathrm{O}_{2}+90 \% \mathrm{~N}_{2}$ & 0.154 & 2480 & 178 \\
$15 \% \mathrm{O}_{2}+85 \% \mathrm{~N}_{2}$ & 0.033 & 3260 & 234 \\
$15 \% \mathrm{O}_{2}+85 \% \mathrm{~N}_{2}$ & 0.154 & 2550 & 182 \\
$15 \% \mathrm{O}_{2}+85 \% \mathrm{~N}_{2}$ & 0.310 & 2310 & 165 \\
$25 \% \mathrm{O}_{2}+75 \% \mathrm{~N}_{2}$ & 0.153 & 2580 & 183 \\
\hline
\end{tabular}

速度の影響をみると, 両者とも昇温速度の増大とともに 低下し，その低下率は昇温速度の増大とともに減少傾向 を示している．また，すべての $E$ の值は一般の化学反 応の活性化エネルギーと比べて非常に大きい值となって おり，鉄鉣不の熱分解㪀匛速度は温度の上昇にしたがっ て急速に増大することが考えられる.

ここで, $\mathrm{N}_{2}+\mathrm{O}_{2}$ 混合ガスおよび純酸素雲囲気にお ける $E$ と $A$ に及ぼす酸素分压の影響について解析し た。昇温速度 : 約 $0.15 \sim 0.167 \mathrm{~K} / \mathrm{s}$, 鉱石粒度 : $155 \mu \mathrm{m}$
の場合， $E$ と $A$ は酸素分压に対して Fig. 8〜9の（a) のように示され, 図 (b)より, 次の回帰式が得られ た.

$$
\begin{aligned}
& E=20730 /\left\{6.543-\ln \left[P_{\mathrm{O}_{2}} /\left(1.013 * 10^{5}\right)\right]\right\} \\
& A=\left\{14.43+\ln \left[P_{\mathrm{O}_{2}} /\left(1.013 * 10^{5}\right)\right]\right\} * 10^{2} / 6.931
\end{aligned}
$$

\section{5. 熱分解反応の予測}

(10)式を変数分離して積分すると次式が得られる.

$$
\alpha=1-1 /\left[1+\int_{0}^{t} \exp (A-E / R T) d t\right]
$$

温度 $T$ と時間 $t$ の関係が与えられれば， $4 \cdot 2$ で得ら れた $A$ と $E$ を(18)式に代入し，数值積分することによ り任意の昇温過程での熱分解反応が予測できる。この方 法で推算した結果と実験結果との比較を Fig. 10 と Fig. 11 に示す。ただし， $\mathrm{N}_{2}, \mathrm{CO}_{2}$ および空気の場合には Table 3 の $E$ と $A$ の值を使用した。両者は分解率が約 80\%までの領域においてほぼ一致することから, 本研
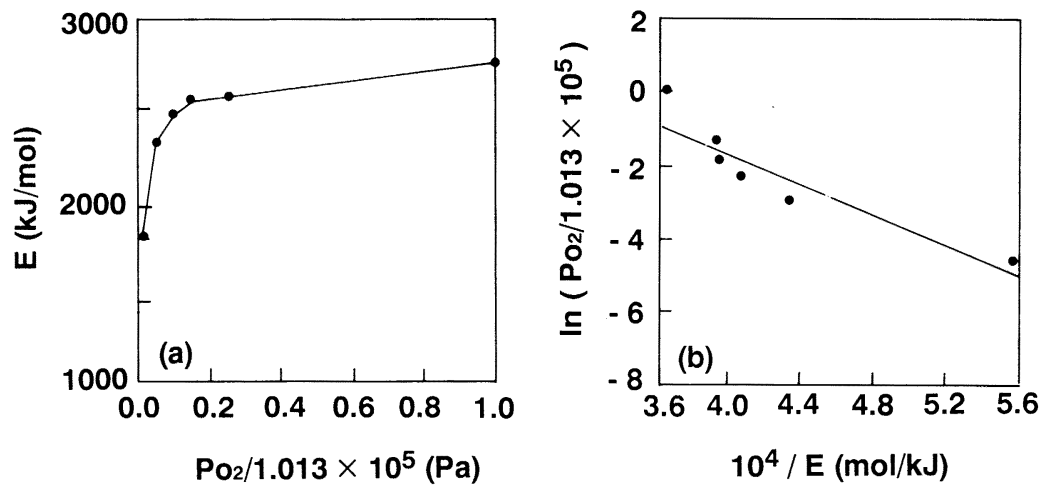

(a) Evs. $P_{\mathrm{O}_{2}}$ (b) $\ln \left(P_{\mathrm{O}_{2}}\right)$ vs. $1 / E$

Fig. 8. Relationship between $E$ and oxygen partical pressure.
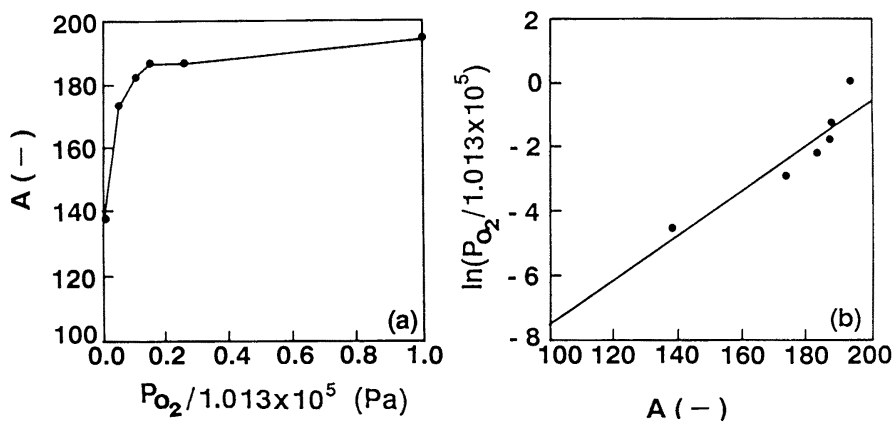

(a) A vs. $P_{\mathrm{O}_{2}}$ (b) $\ln \left(P_{\mathrm{O}_{2}}\right)$ vs. $A$

Fig. 9. Relationship between $A$ and oxygen partial pressure. 


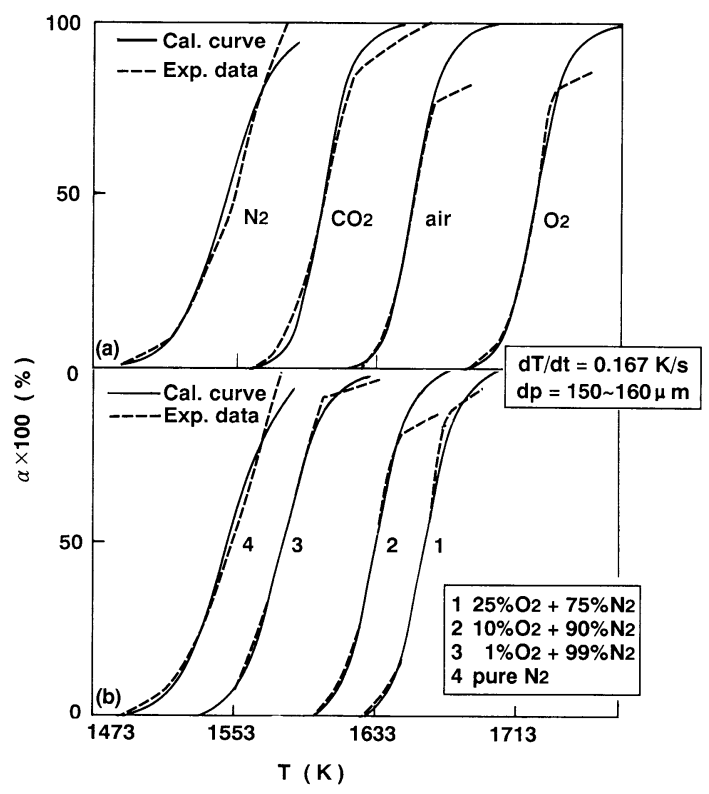

(a) Different gas (b) Different oxygen partial pressure

Fig. 10. Comparison between calculation curve and observed data.

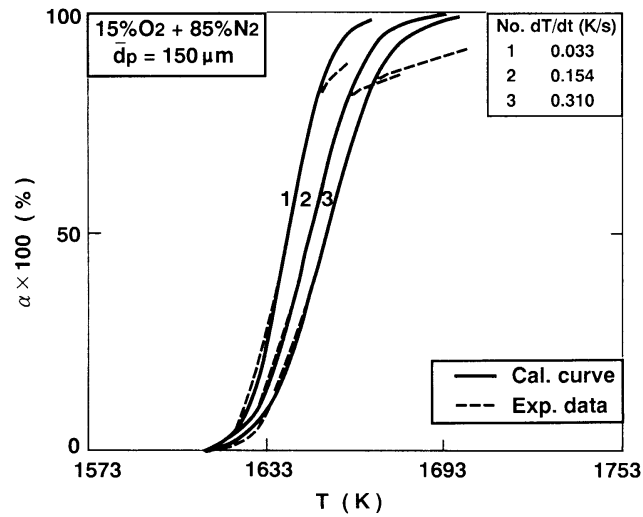

Fig. 11. Comparison between calculation curve and observed data at different rising rate of temperature.

究で得られた速度式とそのパラメーターは粉鉱石の熱分 解プロセスのシミュレーションに十分適用できると判断 される.そこで，（9)式と実験的に得られたパラメー ターを用いて, 高炉レースウェイ条件に相当する昇温速 度下での粉鉱石粒子の熱分解挙動を推定した。

レースウェイ深度を $1.5 \mathrm{~m}$, レースウェイ内の平均ガ ス温度を $2273 \mathrm{~K}$, 平均圧力を $5 * 10^{5} \mathrm{~Pa}$, ガス流速を 約 $160 \mathrm{~m} / \mathrm{s}$, また粉鉱石の飛行速度はガス流速と等し

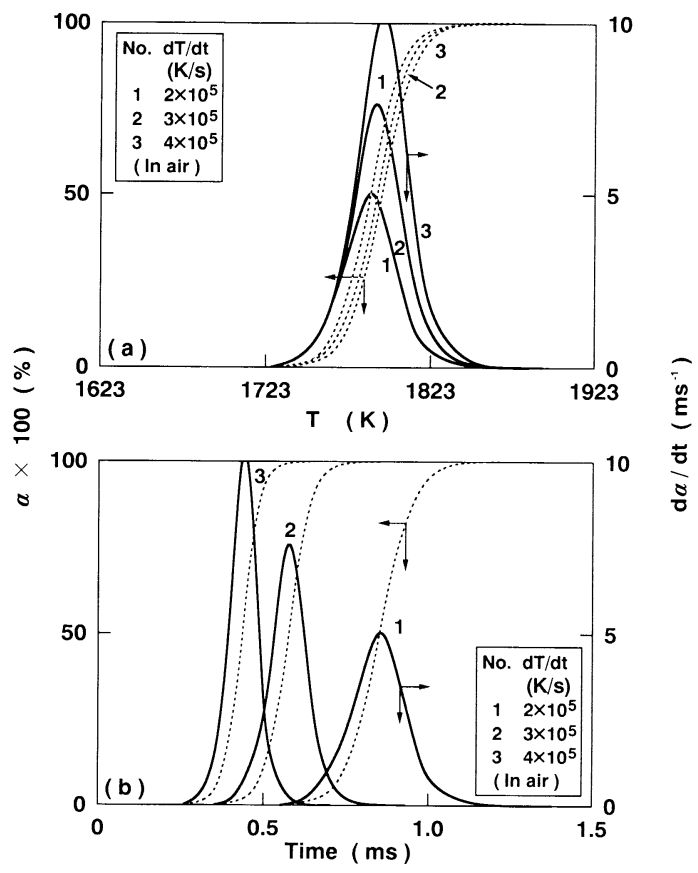

(a) $\alpha$ and $d \alpha / d t$ vs. $T$ (b) $\alpha$ and $d \alpha / d t$ vs. $t$

Fig. 12. Estimated results for thermal decomposition of iron ore at different rising rate of temperature simulating a raceway in a blast funace.

く, さらに粉鉱石は羽口先端からレースウェイ中央部ま での間に $1000 \mathrm{~K}$ から $2273 \mathrm{~K}$ まで加熱されると仮定す ると, 粒子の滞留時間および昇温速度はそれぞれ約 10 $\mathrm{ms}$ および $2.7 * 10^{5} \mathrm{~K} / \mathrm{s}$ となる.レースウェイ内での 昇温速度を一定と仮定し, その昇温速度を $2 * 10^{5}, 3 *$ $10^{5}, 4 * 10^{5} \mathrm{~K} / \mathrm{s}$ の異なる三種類のレベルに設定した場 合の計算結果を Fig. 12 に示す. 㲸の（a）からわかるよ うに，異なる昇温速度であっても熱分解文心はほほ同じ 温度から始まり, 昇温速度が高いほど, 分解速度のピー クと分解終了温度が高温側に移行するが，いずれも $1873 \mathrm{~K}$ を超えるとほぼ分解が終うしている。悯の（b) は時間に対して示したものである，昇温速度が増大する ほど，熱分解が早く起こり，また，分解が古く終「す る.さらに，分解速度のピークが高くなる．これらの計 算結果は 3 章で示した実験結果とよく一致する。レース ウェイ域に吹き込まれた粉鉣石の昇温が前述した範囲に あり，しかも，酸化性ガス雲囲気中での滞留時間を約 5 〜 $10 \mathrm{~ms}$ と仮定すれば，粉鉱石中の $\mathrm{Fe}_{2} \mathrm{O}_{3}$ 成分は約 2 $3 \mathrm{~ms}$ の間にほほ熱分解されて $\mathrm{Fe}_{3} \mathrm{O}_{4}$ に変化することに なる、しかしながら, 実炉レースウェイのような急速昇 温場では，粉鉱石の熱分解反忘に及ぼす伝熱の影響が大 
きいと考えられ，実際の反忠挙動を子測するには本研究 で得られた速度式をレースウェイ内での流れ，伝熱条件 および粉鉱石の熱分解と溶融に伴う吸熱速度などと組み 合わせて解析する必要がある。

\section{6. 結 論}

粉鉱石粒子を高烟羽口から吹き込んだ場合のレース ウェイ内での熱分解成忍について, 熱分析装置を用いて 検討した，得られた TG 曲線から鉱石中 $\mathrm{Fe}_{2} \mathrm{O}_{3}$ の熱分 解反応について, 熱力学的考察と速度論的解析を行い, 次の結論が得られた。

(1)鉄鉱石の熱分解文応は, 反心開始温度扰よ゙応 速度とも䨌囲気中の酸素ポテンシャルに大きく依存す る.

( 2 )雲囲気中の酸素ポテンシャル $\left(P_{\mathrm{O}_{2}}\right)$ が高いほど 分解温度も高くなる。

（３）熱分解必忘は末分解率に関する二次反忍であり， 反応速度定数と温度との関係は雲囲気中の酸素ポテン シャルによって大きく買なる。

(4)得られた速度式とパラメーターを用いてガス雲囲 気および昇温速度の異なる条件下での熱分解過程を推算 した結果，実測値とよく一致した。

(5) 羽口から吹き込んだ粉鉱石が， $2 * 10^{5} \mathrm{~K} / \mathrm{s} \sim 4 *$ $10^{5} \mathrm{~K} / \mathrm{s}$ の速度で宜温された場介には化学仅心律速を仗 定した本報の速度式ではレースウェイ内でほぼ完全に熱 分解し, 還元文応は $\mathrm{Fe}_{3} \mathrm{O}_{4}$ からスタートすると推算さ れた。

\section{記 号}

$A:(9)$ 式に現れる因子，(一)

$a, b, a^{\prime}, b^{\prime}:(4)$ 式と(6)式に現れる定数

$B$ : 昇温速度, $(\mathrm{K} / \mathrm{s})$

$E$ : 反忘速度定数の温度依存性因子, $(\mathrm{kJ} / \mathrm{mol})$

$\Delta G^{\circ}$ : 反忍の標準 Gibbs エネルギー変化， $(\mathrm{J} / \mathrm{mol})$

$k:$ 熱分解应応の見かけ速度定数， $(1 / \mathrm{s})$

$N$ : 物質のモル数, $(\mathrm{mol})$

$N^{0}:$ 最初の物質のモル数, $(\mathrm{mol})$

$n:$ 友応次数

$P_{\mathrm{O}_{2}}$ : 酸素の分压, $(\mathrm{Pa})$

$R:$ 気体走数, $(8.317 \mathrm{~J} / \mathrm{mol} . \mathrm{K})$

$T:$ 温度, ( K )

$T_{D}$ : 熱分解仅忍温度, $(\mathrm{K})$ $t:$ 反応時間, ( $\mathrm{s}$ )

$W_{0}$ : 試料中にある $\mathrm{Fe}_{2} \mathrm{O}_{3}$ の初期重量, $(\mathrm{mg})$

$\Delta W_{t}:$ 実験中試料の重量変化，（mg）

$\alpha:$ 鉄鉱石の分解率, (一)

$\mathrm{X}:$ 鉄鉱石の未分解率, (一)

添之字

$D$ : 熱分解, $e$ : 平衡状態， $t:$ ある時刻， $0:$ 初期， $1:$ 開 始, 2 : 完了

\section{文献}

1 ) 水野 豊, 細井信彦, 元重正洋, 三宅貴久, 中村文大, 山縣千里：鉄と鋼，70（1984），S35

2 ) 福田隆博, 内藤文雄, 浜田雅彦, 九島行正, 高木 泰, 柴田 清: 鉄と鋼, 71 (1985), S88

3 ）春 富大，才野光男，奥村和男，阪口泰浐，稲谷稔厷： 鉄と鋼, 71 (1985), p. 951

4 ）山口一良，上野浩光，内藤誠章，田村健二：材料とプロ 七ス, $3(1990)$, p. 1050

5 ）山い一良, 上野浩光, 内藤誠章, 田村健二 : 材料とプロ 七ス, 3 (1990), p. 1051

6 ）山縣千里, 須山真 - , 堀坆 修, 梶原義雅 : 材料とプロ 七ス, 4 (1991), p. 142

7 ) 山縣千里, 須川真一, 堀坟 修, 梶原義雅 : 材料とプロ 七ス, 4 (1991), p. 143

8 ) 山縣干里, 池宮洋行, 須山真一, 䖯坂 修, 紫富田浩, 柏田昌宏，梶原義雅：材料とプロセス，4 (1991), p. 144

9 ) A. S. Jamaludin, T. F. Wal.land J. S. Truelove Ironmaking Steelmaking, 13 (1986), p. 91

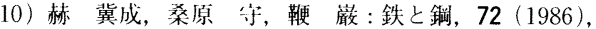
p. 1847

11）小西行雄，武田幹治，田回整司，浜田尚大：鉄と鋼，73 (1987), p. 2004

12) 内藤誠章, 山口一良, 九島行正: 材料とプロセス, 3 (1990), p. 1049

13）桑原 守, 謝 裕生, 鞭峳: 鉄と鐝, 66 (1980), p. 1818

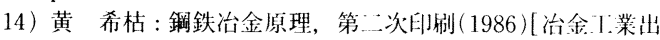
版社（中国）]

15) Л. Л. Рузннов, Б. С. Гуляницкий: Равновесны е Прерашения Металлургических Реакцеи (1975)

16) O. Kubashewski, E. Ll. Evans and C. B. Alcock : Metallurgical thermochemistry, 4th edition [Pergamon Press Lt. England] (1967)

17) S. BAN-YA and M. Hino : Chemical Properties of Molten Slags, The Iron and Steel Institute of Japan (1991)

18）鉄鋼便覽第 3 版,第一卷基礎（日本鉄鋼協会編）（1981） [丸善]

19) E. S. Freeman and B. Carroll: J. Chem., 62 (1958), p. 394

20 ) C. D. Doyle: J. Appl. Polm. Sci., 5 (1961), p. 285

21) T. Ozawa: Bull. Chem. Soc. Japan, 38 (1965), p. 1881

22) A. W. Coats and J. P. REdFern: Nature, 201 (1964), p. 68 